\title{
Effect Of Cucumber Juice And Brisk Walking Exercise On Blood Pressure In Elderly Hypertension Patients
}

\author{
Nufush Chalida ${ }^{1}$ ), Era Ziadatul ${ }^{1}$ ), Felyn Melati ${ }^{1}$ ), Maulinda Dwi ${ }^{1}$ ) Angga Sugiarto \\ nufushcz@gmail.com
}

\begin{abstract}
Ministry of Health Polytechnic Semarang, Magelang Nursing Diploma Study Program Perintis Kemerdekaan Road, Magelang City, Indonesia
\end{abstract}

\begin{abstract}
Background- The treatment for lowering blood pressure can be pharmacological therapy with drugs and also non-pharmacological therapy. Cucumber juice and brisk walking exercise are non-pharmacological therapy that can be done with.

Purpose - Knowing the effect of cucumber juice and brisk walking exercise on blood pressure in elderly hypertensive patients

Method- This research is quasi experiment with pretest and posttest design, using purposive sampling with amount of 40 respondents who were draw with certain inclusion criteria. Data analysis used to assess the differences in the group with paired ttest and between groups using Independent $t$ tests.

Results- The test results paired $t$ test in the intervention group cucumber juice systolic blood pressure and diastolic $\mathrm{p}=0.00 \mathrm{p}=0.00$. The test results paired t test in the group of brisk walking exercise systolic blood pressure and diastolic $\mathrm{p}=0.01 \mathrm{p}=0.03$. Independent test $t$ test in the intervention group cucumber juice and brisk walking exercise with the results systole and diastole $\mathrm{p}=0.017 \mathrm{p}=0.04(<0.05)$, which indicates that there is a difference in blood pressure between the groups cucumber and group therapy exercise brisk walking. On the intervention of cucumber juice for 7 days can lower systolic blood pressure of $10.2 \mathrm{~mm} \mathrm{Hg}$ and diastolic blood pressure of $8.9 \mathrm{mmHg}$. While the intervention brisk walking exercise to lower blood pressure $4 \mathrm{mmHg}$ systolic blood pressure and $3.5 \mathrm{mmHg}$ diastol.

Conclusion - Intervention cucumber juice is more effective than intervention of brisk walking exercise in lowering blood pressure of elderly patients with hypertension.

Keywords : Hypertension, cucumber juice, brisk walking exercise, blood pressure.

1) Magelang Nursing Department, Ministry of Health Polytechnic Semarang

Background. Hypertension is a condition where blood flow is consistently has a high pressure in the artery wall. Diagnosis of hypertension is established if systolic blood pressure above $140 \mathrm{mmHg}$ and diastolic above $90 \mathrm{mmHg}$.

Hypertension is a risk factor for cardiovascular disease and kidney disease. Men and women have the same risk of hypertension. With modified intake of foods that contain

potassium and magnesium become a complementary therapy to lower blood pressure, one of them is cucumber. Cucumber is a vegetable that grows in all seasons and easily obtained in Indonesia and in potassium and magnesium in 100 grams of $153 \mathrm{mg}$ and $11 \mathrm{mg}$.

Research conducted by Lebalado and Mulyati (2014) showed that consume cucumber juice containing cucumber 100 grams for 7
\end{abstract}


days can lower systolic and diastolic blood pressure. A decrease in systolic blood pressure by $12 \%(\mathrm{p}=0.000)$ and diastolic by $10.4 \% \quad(\mathrm{p}=0.000)$, compared to the control group at sitolik blood pressure drop of $2 \%(p=0.077)$ and diastolic blood pressure increase of $1,1 \%(\mathrm{p}=0.419)$. Research conducted by Ponggohong, Rompas, and Ismanto (2005) shows the effect of cucumber juice to the reduction of blood pressure in hypertensive patients $(\mathrm{p}=0.000)$. This is similar to other studies that showed significant difference after intervention cucumber administration in patients with hypertension $(p=$ 0.000).

Besides the management of hypertension based on the pillars of standard treatment and made lifestyle changes that include diet, stress coping organize, regulate the activity patterns, avoiding alcohol and cigarettes. Management of hypertension with medications at this time has indeed been progressed, but there are many reports which said that the patients who come to the hospital will come again with complaints of blood pressure did not decrease significantly even after has been treated. Brisk walking exercise as one of the moderate aerobic exercise in patients with hypertension by using the technique of brisk walking for 20-30 minutes at an average speed of $4-6 \mathrm{~km} / \mathrm{h}$.

According to the research that has been done Sukarmin, Nurachmah \& Gayatri (2013) after brisk walking exercise for 2 weeks (4 days / week, break 2 days) showed a significant decrease in blood pressure in the treatment group systolic blood pressure and diastolic $(p=0.000$ and $p=0.000)$, while the control group systolic and diastolic blood pressure was not significant $(p=0.91$ and $p=0.069)$. Agrees with the results of research conducted by Diana \& Restuning and Ita showed a significant decrease in blood pressure.

Objective, In the research that has been done before, the giving of cucumber in patients with hypertension can lower blood pressure significantly, while brisk walking exercise can also show a significant decrease in blood pressure. Since that, the researchers are interested in developing research to examine the effect of cucumber juice and brisk walking exercise in elderly patients with hypertension that can be used as a therapy non farmachology.

Method. This type of research is quasi-experimental with pre-test and post-test design. The variable in this study is the cucumber juice and brisk walking exercise as independent variables and reduction in blood pressure as dependent variables. This research group the respondents into two groups: group 1 with the intervention of the giving of cucumber juice and group 2 with intervention of brisk walking exercise.

The research was conducted on 25 September to 7 October 2018 in Payaman, Magelang. The samples in this study using purposive sampling amounts 40 respondents with the inclusion criteria blood pressure higher than $140 / 90 \mathrm{mmHg}$, consume drugs and treatment in the clinic, in age 46-65 years old, able to move independently without drawbacks musculoskeletal upper limb and lower and do not have a visual impairment. Respondents were divided into 2 groups: the intervention group of 20 respondents 20 respondents cucumber juice and brisk walking exercise intervention group. In the intervention group performed the giving of cucumber juice for 7 days (1 week) respectively at a dose of $150 \mathrm{ml}$ $(200 \mathrm{gr} / 150 \mathrm{ml})$ while the exercise intervention do brisk walking for 20-30 
minutes for 8 times the intervention in 2 weeks (4 days 2 days of continued intervention intervene again during 4 consecutive days). The provision of these interventions are used to determine the effect of cucumber juice and brisk walking exercise on blood pressure in elderly hypertensive patients.

Systolic and diastolic blood pressure was measured twice using digital spygnomanometer before and after the intervention of cucumber juice and brisk walking exercise.

Test data normality using Shapiro Wilk test. Differences of Group pre-test and post-test intervention cucumber and brisk walking exercise pair tested with $t$ test. The difference of cucumber group with brisk walking group exercise by test the independent $t$ test

\section{Results and Discussion.}

\section{Characteristics of respondents}

Table 1. Characteristics of respondents by gender and age

\begin{tabular}{lcc}
\hline $\begin{array}{l}\text { characteristics of } \\
\text { respondents }\end{array}$ & freq & $\begin{array}{c}\text { Percent } \\
(\%)\end{array}$ \\
\hline Gender & & \\
\hline Man & 17 & 42.5 \\
\hline woman & 23 & 57.5 \\
\hline Age & & \\
\hline $46-55$ & 13 & 32.5 \\
\hline $56-65$ & 27 & 67.5 \\
\hline
\end{tabular}

Based on research that has been conducted which dominates in this study is as much as $57.5 \%$ of female respondents, while $42.4 \%$ of men. This is in line with the opinions of Singalingging in Dwi (2011), which says that the average woman will have an increased risk of high blood pressure (hypertension) after menopause is aged over 45 years. Based on the age of the most respondents at the age of 56-65 years of the 23 respondents. Agrees with Kurniasih in Dwi (2018), says that the incidence of hypertension increases with age, it is due to the decreased elasticity of blood vessels.

Table 2. The frequency distribution of systolic and diastolic blood pressure cucumber and juice brisk walking group exercise

\begin{tabular}{|c|c|c|c|c|c|c|c|c|}
\hline & \multicolumn{4}{|c|}{$\begin{array}{c}\text { Intervention } \\
\text { cucumber juice }\end{array}$} & \multicolumn{4}{|c|}{$\begin{array}{c}\text { Brisk walking } \\
\text { exercise intervention }\end{array}$} \\
\hline & \multicolumn{2}{|c|}{$\begin{array}{c}\text { Systole } \\
\text { pre- } \\
\text { interventi } \\
\text { on }\end{array}$} & \multicolumn{2}{|c|}{$\begin{array}{c}\text { Systole } \\
\text { post- } \\
\text { interventi } \\
\text { on }\end{array}$} & \multicolumn{2}{|c|}{$\begin{array}{c}\text { Systole } \\
\text { pre- } \\
\text { interventi } \\
\text { on }\end{array}$} & \multicolumn{2}{|c|}{$\begin{array}{c}\text { Systole } \\
\text { post- } \\
\text { interventi } \\
\text { on }\end{array}$} \\
\hline & $\begin{array}{l}\text { fr } \\
\text { eq }\end{array}$ & $\%$ & $\begin{array}{l}\text { fr } \\
\text { eq }\end{array}$ & $\%$ & $\begin{array}{l}\text { fr } \\
\text { eq }\end{array}$ & $\%$ & $\begin{array}{l}\text { fr } \\
\text { eq }\end{array}$ & $\%$ \\
\hline $\begin{array}{l}\text { pre-hipertensi } \\
120-139\end{array}$ & - & - & - & - & 4 & 20 & 5 & 25 \\
\hline $\begin{array}{l}\text { Stage } 1 \\
\text { hypertension }\end{array}$ & 8 & 40 & 10 & 50 & 6 & 30 & 5 & 25 \\
\hline
\end{tabular}
140- 159

$\begin{array}{lllllllll}\text { Hypertension } & 12 & 60 & 10 & 50 & 10 & 50 & 10 & 50\end{array}$
stage $2 \geq 160$

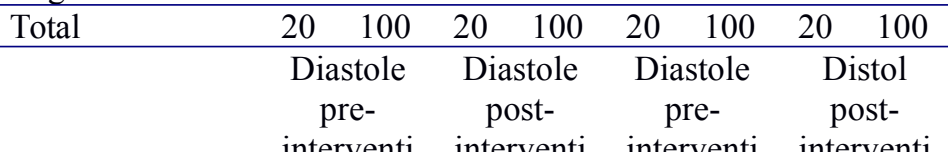

\begin{tabular}{lcccccccc} 
& \multicolumn{2}{c}{ on } & \multicolumn{2}{c}{ on } & \multicolumn{2}{c}{ on } & \multicolumn{2}{c}{ on } \\
\cline { 2 - 10 } & freq & $\%$ & freq & $\%$ & freq & $\%$ & freq & $\%$ \\
\hline normal 80 & 1 & 5 & 1 & 5 & 1 & 5 & 3 & 15 \\
\hline pre-hipertensi 80- & 1 & 5 & 6 & 30 & 8 & 40 & 5 & 25
\end{tabular}
89

\begin{tabular}{|c|c|c|c|c|c|c|c|c|c|}
\hline \multicolumn{2}{|c|}{$\begin{array}{l}\text { Stage } 1 \\
\text { hypertension 90-99 }\end{array}$} & 8 & 40 & 6 & 30 & 7 & 35 & 7 & 35 \\
\hline \multicolumn{2}{|c|}{$\begin{array}{l}\text { Hypertension stage } \\
2 \geq 100\end{array}$} & 10 & 50 & 7 & 35 & 4 & 20 & 5 & 25 \\
\hline \multicolumn{2}{|l|}{ Total } & 20 & 100 & 20 & 100 & 20 & 100 & 20 & 100 \\
\hline \multicolumn{10}{|c|}{$\begin{array}{l}\text { Table 3. The distribution of blood pressure pre-test and post-test } \\
\text { intervention group cucumber juice and brisk walking exercise. } \\
(\mathrm{MmHg})\end{array}$} \\
\hline \multicolumn{2}{|c|}{ Intervention } & \multicolumn{2}{|c|}{ TD } & mean & \multicolumn{2}{|c|}{$\begin{array}{c}\text { media } \\
\mathrm{n}\end{array}$} & $\begin{array}{l}\text { mo } \\
\text { dus }\end{array}$ & $\begin{array}{l}\text { mot } \\
\text { her }\end{array}$ & Min \\
\hline \multirow{4}{*}{$\begin{array}{l}\text { cucu } \\
\text { mber } \\
\text { juice }\end{array}$} & pre & \multirow{2}{*}{\multicolumn{2}{|c|}{$\begin{array}{l}\text { systole- } \\
\text { diastole }\end{array}$}} & 167.8 & \multicolumn{2}{|c|}{163.5} & 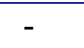 & 193 & 141 \\
\hline & & & & 100.5 & \multicolumn{2}{|c|}{99} & 92 & 135 & 79 \\
\hline & Post & \multirow{2}{*}{\multicolumn{2}{|c|}{$\begin{array}{l}\text { systole- } \\
\text { diastole }\end{array}$}} & 157.6 & \multicolumn{2}{|c|}{159.5} & 130 & 185 & 130 \\
\hline & & & & 91.6 & 9 & & 90 & 119 & 78 \\
\hline \multirow{4}{*}{$\begin{array}{l}\text { Brisk } \\
\text { walki } \\
n g \\
\text { exerci } \\
\text { se }\end{array}$} & pre & \multirow{2}{*}{\multicolumn{2}{|c|}{$\begin{array}{l}\text { systole- } \\
\text { diastole }\end{array}$}} & 157.4 & \multicolumn{2}{|c|}{15} & 145 & 175 & 142 \\
\hline & & & & 95.1 & \multicolumn{2}{|c|}{93.5} & 87 & 117 & 76 \\
\hline & Post & \multicolumn{2}{|c|}{ systole- } & 153.4 & \multicolumn{2}{|c|}{157.5} & 163 & 172 & 134 \\
\hline & & \multicolumn{2}{|c|}{ diastole } & 91.6 & \multicolumn{2}{|c|}{91.5} & 82 & 110 & 81 \\
\hline
\end{tabular}

Based on the research results of respondents group of cucumber juice with a systolic blood pressure of preintervention and post-intervention showed respondents overwhelmingly 
dominated by hypertension stage 2 a number of 22 respondents and blood pressure diastolic pre-intervention of the most respondents with hypertension stage 210 respondents and postintervention show most respondents in stage 1 hypertension is 7 respondents. Whereas in the group brisk walking exercise showed systolic blood pressure pre-intervention and postintervention with the most respondents in hypertension stage 220 respondents and blood pressure diastolic preintervention respondents predominantly in hypertension stage 2 of the 7 respondents while the post-intervention blood pressure of respondents the stage of pre-hypertension is 8 respondents.

Effect of cucumber juice and brisk walking exercise on blood pressure

This study was conducted to respondents elderly hypertensive patients both intervention groups cucumber juice and brisk walking exercise intervention group $(\mathrm{n}=40)$. Interventions such as cucumber juice given to respondents $(\mathrm{n}=20)$ for 7 days in a row while brisk walking exercise intervention $(\mathrm{n}=20) 20-30$ minutes for 8 times in 2 weeks of intervention, excercise for 4 days then rest two days and continued intervention again for 4 days in a row. Respondents cucumber juice intervention group and intervention group of exercise brisk walking are equally taking hypertension medications.

The test results paird $t$ test analysis showed that the intervention of cucumber juice has a difference between the average systolic blood pressure of $\mathrm{p}=0.000(<0.05)$ and diastolic $\mathrm{p}=0.000(<0.05)$ before and after intervention cucumbers. The results are consistent with research conducted Labelado and Mulyati (2014), which concluded that there were significant influence (significant) on the consuming of cucumber juice on blood pressure reduction. Research conducted Kahrisma, Nisfha and Lestari (2012) shows a cucumber proved affect the workload of the heart, potassium pump natrium and bring calmness that ultimately affect the blood pressure. In brisk walking exercise intervention showed no difference between the average systolic blood pressure of $\mathrm{p}=0.010(>0.05)$ and diastolic $\mathrm{p}=0.026(<0.05)$ before and after intervention brisk walking exercise in line with the results Sukarmin, Nurachmah \& Gayatri (2013) that the exercise brisk walking can lower systolic and diastolic blood pressure.

\section{Differences intervention cucumber juice and brisk walking exercise on blood pressure}

Test the difference between the intervention group of the cucumber juice and brisk walking exercise group by using Independent $t$ tests. This test is chosen because the data on these groups were normally distributed $(\mathrm{p}>$ 0.05 ). The test results obtained systolic blood pressure significance $p=0.017$ $(p<0.05)$ and diastolic blood pressure significance of $\mathrm{p}=0.045(\mathrm{p}<0.05)$, which means that there are differences in systolic and diastolic blood pressure in the intervention group and intervention group cucumber juice brisk walking exercise.

In addition it obtained the average blood pressure in the intervention group cucumber juice on pre-test $167 / 100.5 \mathrm{~mm} \mathrm{Hg}$ and posttest 157.6 / $91.6 \mathrm{mmHg}$, meanwhile the intervention group exercise brisk walking on a pre-test was $157.4 / 95.2 \mathrm{~mm} \mathrm{Hg}$ and posttest 153.4 / 91, 6 mmHg. After a mean difference in intervention cucumber juice can lower systolic blood pressure 
of $10.2 \mathrm{~mm} \mathrm{Hg}$ and diastolic blood pressure of $8.9 \mathrm{mmHg}$ and at a brisk walking exercise interventions can lower systolic blood pressure of 4 $\mathrm{mmHg}$ and diastolic $3.5 \mathrm{mmHg}$.

\section{Conclusion and Suggestions}

\section{Conclusion.}

1. Characteristics of respondents who dominate the female respondents and 56-65 years old.

2. The majority of respondents in the group of cucumber juice systolic and diastolic blood pressure pre-test and post-test were hypertensive stage 2. While the majority of respondents brisk walking exercise systolic blood pressure in hypertension and diastolic phase 2 pre-test are at stage 2 while diastolic hypertension post -test currently on pre-hypertension.

3. Intervention of cucumber juice is effective in lowering systolic blood pressure diasto $\mathrm{p}=0.000$ and $\mathrm{p}=$ 0.000 . Likewise with brisk walking exercise to be effective in lowering systolic blood pressure and diastolic $\mathrm{p}=0.010 \mathrm{p}=0.026$

4. The results showed a difference in systolic blood pressure and diastolic $p=0.017 p=0.045$ between groups cucumber and group therapy exercise brisk walking. On the intervention of cucumber juice for 7 days on average can reduce systolic blood pressure of $10.2 \mathrm{~mm} \mathrm{Hg}$ and diastolic blood pressure of 8.9 mmHg. While the intervention exercise brisk walking can lower blood pressure $4 \mathrm{mmHg}$ systolic and $3.5 \mathrm{mmHg}$ diastolic

\section{Suggestion.}

1. For nursing

Expected to be suggestions in order to add information to improve knowledge about the effects of cucumber juice and brisk walking exercise on blood pressure in elderly hypertensive patients.

2. For patients with hypertension in Payaman Magelang

It is expected that hypertensive patients can apply non pharmacological therapy by such as consuming cucumber juice and do brisk walking exercise.

3. For other researchers

Expected for further research using SOP brisk walking exercise that is valid and reliable.

\section{Reference}

Atmayanti. A, 2016. Pengaruh Pemberian Jus Mentimun (Cucumis sativus Linn.) terhadap Penurunan Tekanan Darah pada Pasien Hipertensi. Universitas Airlangga.

Darmojo. B, 2001. Mengamati Perjalanan Epidemiologi Hipertensi di Indonesia. Edika, Juli.

Departemen Kesehatan RI, 2004. Kebijakan Dasar Pusat Kesehatan Masyarakat Tahun 2004. Jakarta : Depkes RI.

Dewi. S \& Familia. D, 2010. HIDUP BAHAGIA dengan HIPERTENSI. Jogjakarta : A Plus Book

Ita, Suranti. 2017. Pengaruh Brisk Walking Exercise terhadap Penurunan Tekanan Darah pada Pasien Hipertensi di Puskesmas Andalas Kota Padang. Padang : Universitas Andalas.

Jamila, Rosita Zahara. 2014. Pengaruh Mentimun (cucumis sativus linn) terhadap Penurunan Tekanan Darah pada Penderita Hipertensi di rumah Sakit Islam Sultan Agung Semarang. Semarang : Fakultas Ilmu Keperawatan Unisula.

Kamaluddin. R, 2010. Pertimbangan dan Alasan Pasien Hipertensi Menjalani Terapi Alternatif 
Komplementer Bekam di Kabupaten Banyumas. Jurusan Keperawatan Fakultas Kedokteran dan Ilmu-Ilmu Kesehatan : Universitas Jenderal Soedirman.

Khotimah, 2013. Stres sebagai Faktor

Terjadinya Peningkatan Tekanan

Darah pada Penderita Hipertensi.

Universitas Pesantren Tinggi Darul

Ulum Jombang.

Lebalado, L. P \& Mulyati, Tatik 2014. Pengaruh Pemberian Jus

Mentimun (Cucumis sativus L.) terhadap Tekanan Darah Sistolik dan Diastolik pada Penderita Hipertensi. Semarang : Universitas Diponegoro,.

Rachmwati, Ika Dwi. 2018. Pengaruh brisk Walking Exercise terhadap Tekanan Darah pada Landia Penderita Hipertensi Esensial di Wilayah Kerja Puskesmas Secang I. Magelang : Poltekkes Kemenkes Semarang.

Saraswati, 2009. Diet Sehat untuk Penyakit Asam Urat, Diabetes, Hipertensi dan Stroke. Yogyakarta : A Plus Books.

Singalinggi,G. (2011). Karakterisik Penderita Hipertensi di Rumah Sakit Umum Herna Medan 2011. Medan : :1-6 (repository.usu.ac.id/bitstream/123
456789/43330/2/Reference.pdf, diakses pada 3 November 2018)

Sugiyono, 2008. Metode Penelitian Kuantitatif dan Kualitatif. Bandung : Alfabeta.

Sumpena, U. 2001. Budidaya Mentimun Intensif. Jakarta : Penebar Swadaya.

Wibowo, M A \& Anita, D C. 2010. Pengaruh Pemberian Jus Mentimun terhadap Penurunan Tekanan Darah Sistolik dan Diastolik Penderita Hipertensi Esensial pada Lansia di PSTW Budi Luhur Yogyakarta. Yogyakarta : STIKES Aisyiyah.

Wiryowidagdo, S. 2002. Tanaman Obat untuk Penyakit Jantung, Darah Tinggi, Kolesterol. Jakarta : Agromedia Pustaka :

Sukarmin, Nurachmah, E., \& Gayatri, D.(2013). Penurunan tekanan darah pada pasien hipertensi melalui brisk walking exercise. Jurnal Keperawatan Indonesia, 16 (1), 33-39. Diakses 26 April 2018.

Subakti, S. (2014). Pengaruh latihan jalan kaki 30 menit terhadap penurunan tekanan darah pada pasien hipertensi di Rumah Sakit Umum Kabanjahe. Jurnal Pengabdian Kepada Masyarakat, 28 (77), 1-15. Diakses 26 April 2018. 